\title{
Race \& Criminology through the lens of a sociologist
}

Interview with Natalie Byfield

\author{
Letícia Simões-Gomes* \\ https://orcid.org/0000-0002-6329-6115 \\ Alcides Eduardo dos Reis Perón* \\ https://orcid.org/0000-0003-4537-2775
}

Natalie Byfield is professor in the Department of Sociology \& Anthropology at St. John's University, Queens, United States. She has a background in scientific inquiry on media and society, cultural studies, social theory, and the combined aspect of race, gender, and class formation. She is the author of Savage portrayals: race, media and the Central Park jogger story (Byfield, 2014). Currently, her research interests can be ascribed to Critical Race Studies, and have been focused on new forms of racialization, policing, and informational capitalism. This interview was conducted on October 4th, 2019 by video-call. It was recorded and later transcribed. All references mentioned can be found at the end of the interview.

Letícia Simões-Gomes (LS): Professor Byfield, thank you very much for your time, I'd like to begin with a question about your trajectory, which is quite interdisciplinary. Please correct if I am wrong, but you have started your studies in journalism, is that correct? How would you describe your career?

Natalie Byfield (NB): I actually started my studies in politics and political science. I initially started my PhD work in Political Science at Stanford, back in the early 1980 's. I wasn't really a fan of the program there, so I decided to move on and work

* Universidade de São Paulo, São Paulo, Brasil. 
in politics. While I was working in politics - in particular I worked at a lobby for African and Caribbean Transafrica, and I also worked for the Jackson campaign for president in $1984^{1}$ - I was able to meet a lot of journalists, and I realized that journalism was not just a very interesting profession, but one in which I could make some important contributions. So I pursued a career in journalism after working at the Jackson campaign.

Alcides Perón (AP): You have published a book called Savage portrayals: race, media $\&$ the Central Park jogger story. How did you get to this subject?

NB: Well, I got to this subject through my work as a journalist, essentially. I worked with different types of publications, and I finally landed at the New York Daily News (DN) in 1987, which at the time was the largest daily newspaper in the Us in terms of circulation. There I simply covered a lot of different things, I covered business for a while, and I landed in what they called the "city desk", which was the major desk at the DN. There, you often do a lot of general interest stories, and you also (given the type of publication that $\mathrm{DN}$ is, a tabloid) do a lot of street crime stories. So it was in that context that I was assigned to the story in April of 1989. I was one of several reporters assigned that day to cover the sexual assault, the rape of the woman jogging in Central Park.

LS: Would you mind to explain the media representations about the Central Park case that you mention in this book?

NB: What I tried to do with this book was to discuss the case in a very layered way, in the sense of using multiple perspectives. So one of the lenses that I brought to the case was that of a Black woman living in New York City (NYC), growing up like all immigrants had grown in NYC. Another lens was that of a journalist who had a fairly front row seat on the coverage of the case. The third lens was that of a sociologist. So was this multiple perspective that I wanted to bring the conversation about the case and how the case was covered. From the point of view of being a Black woman in NYC, I knew instantly that there was a major difference in the way media was approaching this case, and there was a great likelihood that the difference in approach had to do with the race and class of the woman who had been attacked, and also the race and class of the people who were the suspects. Also to the ages of the suspects.

1. Jesse Jackson was the second African American to gain prominence in the primaries of the Democrats for the 1984 presidency run. He was a civil rights activist from Illinois, and was the third most voted candidate at the time. 
There was a difference in the approach that the editors were taking, and I knew that. Whether or not I was a journalist, I would have recognized it, but being in the newsroom in that particular point and time - when newsrooms were still very segregating places (and in many respects mainstream news media organizations lack proper diversity) - I saw these things up close. I had the lens of a Black woman from NYC, who was in this newsroom at a time that was not only not very diverse, but had gone through a racial discrimination lawsuit - and lost. There were racially antagonistic feelings within the newsroom, as well as where we were in a society at that point in time.

LS: We don't have this book translated in Portuguese yet, so would you mind drawing the book's major argument?

NB: The book tackles the relationship between the media and the police, and the impact of that relationship - and I should say the media, and the Criminal Justice System, the police and the prosecutors in particular - on the case coverage. And what it is basically arguing is that the mainstream media serves as a very non critical mouthpiece. In the case coverage, the narratives that took hold and were delivered to the public were narratives that came straight from the police and the prosecutors. They weren't critiqued at all. So the media had essentially abdicated their responsibilities to act as this type of Fourth State over institutions and the society. There is a likelihood, given the racial dynamics in the media, that they were influenced in part by their own racial biases and felt some type of allegiance.

So you get this sort of racial allegiance, or White supremacist attitude operating across institutions when it comes to a case like this. The notion that you were getting some sort of fairness and due diligence and the media operating in a way to carry out its "stated duties", "stated obligations" and operating independently just didn't happen. Whatever the prosecutor said was put in the paper as facts. It rarely mattered whether or not they cited sources that were supporters or advocates for the suspects at the time. That is because the way in which the media is set up, and the way in which it operates - particularly in the delivery of the representations in the stories that we get - makes possible that the ideas that are not dominant can be subsumed by dominant ideas. We never really get this multiplicity of perspectives that can be achieved from a "marketplace of ideas". We're still getting dominant ideologies that determine how we need to look at things to serve dominant interests. 
AP: Was at this point that your interest in the Criminal Justice System arose?

NB: Well, yes. I really watched the way the media covered this. One of the stories that stood out to me, was a story that I wanted to write about - the impacts, the aftereffects of the jogger's rape, and then the police investigation, in terms of just doing their due diligence to figure out, find out, investigate, come up with what happened.

One of the things was that the precinct in Central Park, which is where the rape took place, had created a policy for daily operations. This policy dictated that, when on patrol in Central Park, the police should stop groups of Black and Latinx teens, young people, and demand that they produced identification. If not, they were to be evicted from the park. I immediately thought of passbook law - this was like South Africa, where your ability to use a space was dictated by the race classification in which society has placed you and the police is supposed to enforce it.

So I went to my city desk editors to pitch this story, and I was stunned when I saw indifference, this sort of "well, you know, maybe try that desk, try this other desk". Then finally I went to the Sunday desk, because at that time the Sunday circulation was the largest (at that time, DN's Sunday circulation was about 1.2 million). I was thinking: if no one else wants to do it, I'll go to the Sunday editor and ask. He looked at me and basically said: "What, are you angry?". I literally couldn't process what he was asking me, I thought he was asking if I was angry at them, because they were jerking me around, and they had no interest in what was obviously an important story.

That story is part of the coverage of what they had dictated as the city's biggest story. They had no interest, and he was asking if I was angry. Then I said, "angry, angry at what?". I was also thinking about it professionally, if I display anger, then it is all over, and they will come up with that excuse for not using the story. I then realized that what he was really asking me was if I was angry that the kids were getting stopped. He couldn't even imagine that there were legitimate journalistic reasons to run this story, and this wasn't just personal anger of the Black woman in the office. So that really made me angry, because I recognized that they thought that as a Black journalist I couldn't do my job impartially, and I couldn't come up with professional reasons to run this story. This is very typical of the way Black journalists are treated, there's an assumption that we can't cover other Black people and be impartial, but White journalists cover White people all the time, and we are supposed to accept that as objective reporting.

So, I organized my thoughts to give him the journalistic reasons, and his attitude was: "Certainly you can understand why the police is doing it now, it will go away, it will go away". That's what it was like for me working in mainstream media in the late 1980's. This is a period in time when American society claimed that we had arrived 
at a new moment of color blindness, where the civil rights movement had taken us to a new place where these gains were being realized, and racial barriers had come down. But that's what the reduction of racial barriers looked like at that moment.

To me, that story indicated so much about how media worked, and how the principals involved in these media organizations thought then. Not just in general, but specifically about racial issues, and racialized gender issues. Ultimately, I was seen as a hysterical Black woman, angry at the way the Black kids were being treated, and that's why I wanted the story in the paper. "Well, hello! This is like passbook law in South Africa. Our constitution in the us shouldn't allow for this". It didn't seem to matter, and so I had to fight for that story, and I went over his head to the editor in chief. That editor did agree with me, and allowed me to pursue the story. I got information, and important information for the story from police sources, but I did not have in-person interviews with the police in the precinct. Although some were giving me information, I knew I couldn't meet with them.

I got a civil rights attorney to comment on this. When the time came to run the story, this other thing happened. I submitted the story, and then I got a call over the weekend - and it was supposed to run in the Sunday paper - and the call came from the editor in chief. Then, you know, there was some dispute going on about this, and they had pulled him into it. The editor said "Oh, we can't run this, there's something about it", you know, essentially the usual nonsense. So they didn't run the story at first, and I kept asking about it, and they hung on to it for about a month. It eventually ran a month later - instead of running it in the Sunday section, they ran the story in the Saturday paper, which had the lowest circulation of the week (200,000 copies). It ran on the obituary page, and was cut to a less than half of its size. Instead of "Cops targeted kids", the headline read "Cops targeted kids?".

\section{LS: After this episode, you have left journalism. Did you decide to teach? What happened?}

NB: I left daily journalism in part because the news were going through a terrible financial time. The newspaper where I worked, the Daily News also went into receivership, and a new person bought it. Then, one of the agreements of the purchase was that they would cut the staff by something like a third. Given my relationship with my editors, I was gone. I was a problem.

So I had to make a decision then. Did I want to stay in daily journalism? I decided I'd rather teach about daily journalism, and teach about how media operates. I thought I would have a bigger impact on the future than fighting these people in very, sometimes, singular ways. It is one person against a battalion of editors over a particular story. 


\section{LS: Then you went from Media Studies and then moved to Criminology?}

NB: Well, I was teaching journalism. I actually was the director of the Journalism Program at Queen's College, in the City University of New York System, so I taught journalism for a bit. Then I got involved with community work around media literacy, and helped school districts and community organizations to build media literacy into any curriculum they created, so that people could develop techniques to read and access media, mainstream media with a much more critical lens. So I did that for a bit, but I wanted to do studies around media, and decided to go back to school to do a $\mathrm{PhD}$ in Sociology. One of my main areas of focus would be race and media.

When I went back and worked on this PhD around 2000, my plan was to write a dissertation on the Central Park case. This was before people were even talking about its meaning and significance. By then, these poor kids had languished in prison, came out of prison (some of them) and were in different stages of the post-conviction, or the post incarceration process. Those released had been forced to be registered as sex offenders. Given all that, I decided to take up and re-examine this case through the lens of a sociologist. While I was developing this work in graduate school, the district attorney re-opened the case.

In the re-examination, the district attorney accepted the word of the person who was the actual perpetrator: that he acted alone. His DNA did in fact establish that he was the person who had committed the rape. After the convictions were vacated, much of what these young men who had been wrongly convicted did was go around from community to community where they were invited to talk about what they experienced, and why this could happen to anyone - in particular, why it had happened to them as young Black kids in a relatively poor neighborhood (Harlem) in the 1980's. They have consistently done this work. What has changed is the public acknowledgment and recognition, and as that continues to be transformed, you see this story spreading globally.

LS: Moving a bit to your study of the Criminal System, what are your views about the ways Criminology scholars tackle race and ethnicity in their studies? Do you feel there is a hegemonic approach to race? Is there an approach to race?

NB: Well, I am someone who is more aligned with the Critical Race approach, because I think race has to be centered in the study of Criminal Justice in the Us. The research that I have done, particularly about the development of policing in the Us, makes it very clear that one of the elements of policing is the incorporation of the White gaze. Historically, the function of policing was to protect the White settlers 
or colonizers from anyone else who presented a threat to them. Which also meant anyone who presented a threat to their agenda, included the capturing of land and the enslavement of Africans and Native-Americans.

Thus, operating against that was defined as criminal. Given this historical foundation, we have to center race in the analysis of the study of criminality, crime, and the Criminal Justice System in the Us. As the Us started out as a settler colony - where the Europeans developed themselves as a group of Whites operating antagonistically against indigenous people and against people that were stolen and brought here from Africa to do their work - race has to be centered in the study of the Us Criminal Justice. This for me is essential, and this is my approach. Other criminologists do not take this approach, and I recognize that, but I'd critique them historically.

AP: There are several similarities between your work and some researches conducted in Brazil. This said, how do you address the literature that is being produced about racel ethnicity and policing in countries other than the US?

NB: I think I've read mostly the literature in the UK. My work has been heavily influenced by Stuart Hall; Policing the crisis (1978) is a very important book for me. It's a seminal work for people trying to understand the ways in which States, in general - not specifically Racial States, that have racially diverse populations - operate when there is a crisis among hegemonic powers. For me, the need to combine an analysis and an assessment of capitalism, the cyclical crisis that capitalism experiences, and the desire of Whites in Colonial States (and the us is also a Colonial State and a Colonial Power) to maintain their dominance and their hegemonic positions, those things have to be incorporated in our understanding of and assessments of how racism and criminalization operate independently and intersect. In the us they turn what is essentially a race problem into a crime problem, (the 2016 work of Naomi Murakawa shows this) because what you have at the heart of what is happening here are racial conflicts. However, those who are in hegemonic positions are able to construct ideologies that are distributed through narratives that turn this race problem into a crime problem. Essentially, the narrative "we (Whites) are protecting ourselves" is what became the dominant position, and "protecting ourselves against the hordes who would seek to harm us".

LS: Currently, your work has been more focused on blackness surveillance. How did you get there?

NB: So, the examination of the Central Park case has been very critical for me. My research on that case really highlighted the role of police and how policing is, in part, 
a way to surveil blackness, a way to surveil groups that have become "Otherized". So, if we were to look specifically at the elements of the Central Park case that brought to me to this, toward the end of the Savage portrayals book project, I had to ask myself what allowed the police to detain the kids the way they had detained them. You could immediately see race and class played major roles in this. Had they come from wealthy families, the police would have taken a totally different approach. Had they come from White families, or even poor White families, there's a great likelihood that it would have been approached differently also.

What we had here in this particular case was the presumption of guilt, from the beginning. I did a content analysis that I reported in Savage portrayals, in which I examined a randomly selected group of articles (about 251 articles) published by the New York Times and the Daily News. This examination showed that 12 articles - not $12 \%$ - used the term alleged. I have already stated here that what we were getting in these articles were essentially this unfiltered narrative from the police and the prosecutors. Through this content analysis I have re-established the presumption of guilt from the start.

From there, I could see the implicit biases, the standard biases playing out: the racial ones, and the class ones that criminalize blackness. Regardless of that, the police had to have some kind of legal footing to stand on to detain some of the kids. For some of them, or a couple of them, they were picked up that night, on the street. So, I thought, why them? Why would they pick them up? Did they see them in the park close to some site of crime going on, had someone identified them? The police had received reports of other incidents happening in the park that night that they were investigating. On what basis did they pick up some of these kids? The police were able to just stop them and just pick them up or detain them - and I am now particularly speaking of Raymond Santana, who wasn't even in the park, when he was detained. Kevin wasn't in the park, Raymond wasn't in the park - actually Kevin ran back into the park when the police started coming after him -, so on what basis did they get picked up?

Imagine, you are walking or maybe running down the street, the police are investigating a case in a location that while it may be near to you, it's not your specific location. That could trigger a police detainment. So you have to have a justification to pick them up, unless you can just randomly pick people up. The point is, the law behind the police practice "Stop and Frisk" allows police to detain people, question them, and frisk them based on "reasonable suspicion". This law was based on a case decided by the United States Supreme Court in 1968. The Court ruled that such stops did not violate your Fourth Amendment rights, constitutional rights, against unlawful searches and seizures. After the Terry Law in 1968, the police were able to 
enact or to claim "reasonable suspicion". So, what is "reasonable suspicion" based on? Whatever implicit bias the police have, it is incorporated in their decision to stop people. The people that they typically stop are Black people, people from Latinx ${ }^{2}$ communities. It's how Stop and Frisk was enacted in NYC that was important for the context of the Central Park case.

In the aftermath of the Savage portrayals, I started this research on Stop and Frisk. It became more evident that, after the Giuliani administration, the deployment or application of Stop and Frisk practices were very much about surveillance. It wasn't specifically attached to a crime being committed, it was attached to this premise, or this approach to policing that is labeled as "proactive policing". We essentially had a new type and level of surveillance. Initially, when Giuliani's police commissioners began to increase the use of Stop and Frisk, they didn't necessarily collect data on people who were stopped. After a certain point in time - by 1997 - the NYPD 3 started enforcing a rule that when police detained someone in a Stop and Frisk: they had to fill out of a form called UF250, which collected all types of data on the people that were stopped. So Stop and Frisk was not simply a legal way in which police could randomly stop people because they thought that they might be involved in something suspicious. Police were also able to collect data on the people that were being stopped. At that time, police were also incorporating a lot more computer technology - we're talking now about the 1999's and the technological revolution taking place. They were applying all of these analyses to the data that they were collecting. So we were moving into Stop and Frisk becoming the foundation for a more expansive racialized surveillance in NYC.

AP: Recently, we have been witnessing a new hype in police studies: the so-called predictive policing. How do you feel these tools impact surveillance and surveillance over Black people specifically? Does it relate to your concept of existential crimes?

NB: Predictive policing is going to drive more and more surveillance, because it is based on data analysis, that is, using predictive analytics along with the application of algorithms to the data. Predictive policing is going to drive more surveillance and more types of surveillance that will feed data into the system. I believe that part of what was happening in the late 1990s and 2000s was the police turned to digital platforms, and the data importance grew. Now we are living in a type of capitalism that is really being based on data, and its collection, accumulation, use, and analysis.

2. Latinx is a gender neutral way to address communities of Hispanic descent.

3. New York Police Department. 
I mentioned that some researchers use the term "Information Capitalism", Zuboff (2019) is using the term "Surveillance Capitalism". Whether or not the data is being collected for the purposes of serving the work of those in the Criminal Justice System or not, all elements of the current system of capitalism are in fact demanding or needing this data. The current type of surveillance derives from data analytics. So in every area of production under this system, we are being driven by the internal logic of assessing the data, which means classifying the data for analytic purposes. Data classification is part of the surveillance process, that's how surveillance works.

When I discuss it in this way I am thinking about Foucault, where surveillance is about separating one thing from the other and still being able to maintain the logic for this distinction. So the systems of production that we have now are being driven by data surveillance; data is ascendant, it's the fuel for the system at this moment. For example, technologies used within the Criminal Justice System allow their operators to reach across to other areas - such as other types of data and information -, and incorporate them into their analysis. In general, the police have access to databases outside the Criminal Justice System. Social media posts is an example. Another one is the access to DNA collected by companies that analyze it to determine people's roots or their background. In the Us, if the police are investigating someone to whom you are related and for whom they do not have any DNA data, they can access this private database where your DNA information is stored. So, even though you have nothing to do with the Criminal Justice System, police can use your DNA info to help them in the case involving your relative who they are investigating.

Because data and the technologies associated are operated this way, it is easier for the state to enact types of surveillance that we never imagined them being able to do. There is a lot of questions that need to be asked about the surveillance of all types of data, not just those specifically related to the Criminal Justice System. If I hypothetically send my data to one of these ancestor's tree type companies because I am interested in finding out and meeting with possible cousins across the globe, I think I am operating as an individual, but I am not. It will have an impact on people who may be related to me, who did not send their DNA in. That is because the State has access to that to serve its needs - in particular to serve Criminal Justice System's needs.

So what's happening here is a fundamental transformation around issues related to who and what an individual is. What I am describing to you is the research of Alondra Nelson (2016). I'm thinking about her work as I'm talking about the ascendance of data and its particular impact. It's not just data that the police are collecting, it's also what they have access to. Data is ascendant also because of the technologies available. Then, given the logic of policing - in that it's a racialized 
phenomena - and its racial biases, you can think of the extraordinary impact this could have on discriminatory behaviors against people of color.

LS: In this regard, is it possible to assume that these new predictive techniques are in fact crime construction techniques? So that they are oriented to reinforce and reproduce those patterns of discrimination you were talking about?

NB: Within the context of the predictive technologies used by the police, I believe it's important for us to look at those technologies and their input with a great deal of skepticism. All of this work must be heavily critiqued. If you look at the history of policing itself - and I'm thinking in terms now of New York City and the Us in general, because that's the focus of my empirical work - I think of the ways policing has been so disproportionate from a racial perspective. The hyper-policed communities, which are Black and Latinx communities, are the communities with most data on. The racial disparity associated with hyper policing leads to racially disparate data about crime. If you police more, you are going to have higher crime rates. Also, the history of hyper policing can be traced back, and so crime data should always be considered suspect, just from the general premise of how policing operates. The critical approach that must be brought to the crime data is not happening in the context of this predictive analytics.

AP: We would like to relate this point to Benjamin's work Race after technology' (2019), and O'Neil's Weapons of math destruction (2016). Ruha Benjamin considers the existence of a color blindness ideology, as you have assessed in this interview, but these colorblindness ideologies are also expressed in algorithm developers who never consider the harm caused by them in racist designs in everyday technologies. Is it possible to affirm that these security technologies have racial bias by design? What could be done to avoid it?

NB: [laughs] That's a big question!... I mean, the examples abound. To fix the problem you would have to be able to ensure that the original data that is input in the system was not generated in a way that is racially biased. So that's one thing. And I've just mentioned how the data that's being put in the system is biased by itself.

And then there are algorithms themselves: we would need to see the algorithms, there has to be algorithmic accountability and transparency. Without that, I cannot accept them as unbiased, because I have to be able to see the categories and the classifications in which you are placing data to do the analysis. And if I can't see that, how can I make the assessment? These are some basic fundamental types of 
approaches that have to be taken. And typically, what we see in policing circles, the typical thing is not to reveal the algorithms, because they are considered proprietary.

LS: You were talking about past data and most of this data is usually related to some allegations of racial profiling. In one of your talks in Brazil last August you have argued that it's insufficient to talk about racial profiling, when addressing police discrimination over Black people. I wanted to ask you why is that? Why is it insufficient?

NB: The more I work with the definition of racial profiling, the more it feels inadequate, in terms of what is actually taking place. There's such a deep and a long history taking place that's reflected in the way policing is done. To wrap up the disparate stops, the racially disparate pedestrians stops in stop and frisk, or the racially disparate traffic stops, simply as racial profiling, seems to diminish what I think represents a bigger logic: that of the Racial State over control and repression of Blacks and other people of color.

Racial profiling just seems so small when you consider the ways in which lives and communities get derailed by these practices. Part of what's going on there is not simply that police are stopping Black and Latinx people, it's about the likelihood - given the levels of policing, the amount of policing, the levels of policing going on and then accompanying the racial profiling - that these things are feeders of the system of mass incarceration. The work of Michelle Alexander (2010) revealed this. And the system of mass incarceration is more than just about locking people up, and locking up too many people. It's a systemic way in which the State eliminates and removes from the population of people who have access to rights as citizens, the people who look a particular way or who have been "Otherized".

So, what they're doing is racial profiling? In a way, sort of, but what they are actually doing is eliminating people from groups that are considered citizens and for some people groups that are considered human. Therefore, it's a much more massive thing underway, and it feels that way to me when I study it. For example, the Stop and Frisk led to high rates of Marijuana arrests in NYC among young people of color (Blacks and Latinxs communities). These disproportionately high rates of Marijuana arrests do not reflect anything remotely resembling the actual rate of use of Marijuana by Blacks, Latinxs, and Whites. Their rate of use of Marijuana is almost the same. It's simply the hyper-policing that gets higher arrest rates. But what that does is it derails lives, and communities, and these are not minor things.

If you are increasing the rates of arrest in Black and Latinxs communities, as compared to White communities, if you are increasing their rates of incarceration, what you have is that they live life in a Carceral State. To term it racial profiling 
suggest that the logic of the State we live in operates the same way for both of us, but there's this disparity in certain things. No, the logic of the State comes totally different in regard to the treatment dispensed. You end up in a position where if you are convicted of a crime, you may not have access to public housing, and if your family may be living in public housing and they bring you in, they could lose their housing. So it's a complete destabilization of people's lives and communities, and it doesn't operate that way for White communities. People can get convicted, go to jail and come out - I'm not saying reintegration is easy, but I'm suggesting that there may be a community to reintegrate into, where Blacks and Latinxs may not have anything to reintegrate into.

LS: How does this process you were talking about relate to the concept you use of 'existential crimes'?

NB: It relates in this way in that the system seeks to expel us. What would you expel except something that operates as a threat to your existence? What I see is that there are behaviors that Blacks and Latinxs participate in that are viewed as a threat, from the context of the dominant logic of settler societies, which are essentially White States. The authorities protecting the White State seek to expel things that represent a threat to them, and so some of our behaviors represent not simply crime, but existential crimes.

Ls: We were talking about racial profiling. Here in Brazil, we use the notion of racial profiling relating to the racial disproportions of deaths due to use of deadly force by the police (but also regarding arrests in flagrante delicto ${ }^{4}$ ). So, here, we have a great disproportion when considering those deaths, and that's what we call racial profiling. When we talk about reducing police violence in Brazil, we try to develop some kind of policy to reduce the aggregate. So, to reduce police violence in general, but not looking into the racial disparity of those victims. Do you feel this racial disparity would go down if we just reduced police violence? Do you think that's enough?

NB: No, it's not enough, because the disparity is really a measure of the rate of difference, and so you will still have the disparity even if the number of violence incidents are coming down. You would still have the disparity because you are not addressing it. If the policy is governing police practices that leads to violent responses from the police, then, okay, let's say it brings down the number of violent incidents. You may

4. Legal term used to indicate that a criminal has been caught in the act of committing an offense. 
still have two times the amount of violent incidents in which the victims are Blacks. And so, it's about transforming, first of all, the value you place on Black lives.

LS: So, how do you feel the problem of racial disparity in police violence should be addressed?

NB: You need to place in the foundations of society. To change the value placed on Black lives. You know, Black lives matter. I see sometimes in the United States how much that term just upsets people, because they want to say 'Well, all lives matter!' No, they're missing the point: Black lives are actually not valued, or very little value is placed on a Black life. And as a result of that kind of logic that permeates the entire system - because the State is not just the government, it's also the ancillary agencies and the logic of the State system that is then applied to all other institutions. This logic permeates the system, so you have to change the value placed on Black lives. And that would require fundamental foundational changes.

\section{LS: So police changes are not enough?}

NB: They are necessary, but they are not enough. It's necessary to make the police less violent towards the citizenry, but at the same time, the lesser violence from police forces is not going to - in my estimation - reduce the racial disparity in who is victimized by police violence unless you have the equal value placed on all the lives. You're not getting that in Racial States that seek to distinguish and separate out what has been defined as a threat to the State - and one of the things that defines you as a threat to this Racial State in which whiteness is dominant is being a person who is not White. So you are initially viewed as a threat, so that immediately establishes that your life is not being of the same value. We have to address these fundamental things. There are lots of institutions that need to play a role in the transformation of the value placed on Black lives. One of the ways is through the educational system, we can actually teach the histories! So that people start to learn that when you hear complaints of unfairness from Blacks it's not because they woke up with an attitude problem, but because there is a long history of maltreatment, of inequality.

LS: You have mentioned the concept of Racial State and White gaze. Would you mind expanding and also explaining the importance of those concepts to your framework?

NB: The concept of Racial State and White gaze are very important to my framework, and I am borrowing from the works of David Theo Goldberg (2002), and 
of Simone Browne (2015). David Goldberg wrote the book The racial state to talk about the logic of how Racial States operate, in particular when we are studying settler societies. We have to think in terms of what that logic means, because these societies are founded on the premise of racial distinction, racial demarcation, and a dominant racial group. Is that dominant racial group reproducing its dominance? One of the things that this group deploys is a particular view that is part of the internal logic of the State, in order to maintain its dominance, and that is where the White gaze comes from. This lens is used to assess the people, the workings, the apparatuses of the State, the apparatuses in the society, to ensure that the perspective that becomes dominant is in fact the White perspective. So, the racial gaze, rather the White gaze, is important to think about. Stuart Hall also wrote about the racial gaze, about what gets defined as important and what gets defined as necessary for development, for reproduction of all the elements of the world that we're living in. That gaze demarcates what counts and what doesn't count.

Ls: While you were talking, I was thinking about the discussion of post-colonial studies regarding the processes of colonization. How this understanding of Colonial State would differ, for example, from that of the Racial State? Is there an intersection between those concepts?

NB: Well, one of the things I think that's really important, when you're thinking about Colonial Powers, is that - and I'm largely referring to Great Britain - you can actually tie the development of Racial States - let's say in the 'New World' - to the development of things like the enclosure movement in Great Britain, that displaced people due to the privatization of land. This in part contributed to the movement of people to the 'New World', and it's part of the process of building up Colonial States. Here I'm describing the work of Gurminder Bhambra and John Holmwood (2018). That's why, in a very concrete, material sense, you cannot separate the colonies from the formation of race.

Even though you will hear Europeans States that were Colonial Powers talk about not having the same type of race problem because they were racial monoliths - not racially diverse -, you cannot separate the formation of the Racial States from the transformations happening in Europe around capitalism. The rise of capitalism in Great Britain is the example I'm using, and the enclosure movement really plays a major role in what ends up developing in the 'New World'. This is all part of the racialization process, because they're coming here and essentializing whiteness as distinctive. These are related to the 'Otherization' in the Colonial States. 
LS: That relates in some aspects to the next question; there are some Black academics and intellectuals that are currently saying that they ought to move beyond sociology of race and ethnicity to other fields, and help to build up a Black epistemology. What are your thoughts about that?

NB: I think it's necessary to be done, because - and of course the question of the White gaze is totally related to it - what the White gaze is doing is imposing this dominant perspective on blackness, which is important to the reproduction of whiteness and of White dominance, because it establishes how blackness is defined. So that White gaze is coming from a particular epistemology about the world, how the world is divided, what things mean, who gets to set meanings, and so we can't get beyond that.

We won't be in a position to have a more realistic understanding of how the world works unless these other epistemologies are developed, because people experience the world differently based on their histories, their backgrounds, and their geographical location. To assume either the subordinate or negative meaning to regions of the world and peoples from those regions actually plays a role in eliminating or refuting knowledge from those areas. And yet, you take this White gaze to your science - whether it's the hard sciences or the social sciences -, you turn around and tell us that "well, we have a very complete and developed paradigm that we are using, that's helping us to have the best understanding of how the world works", and you negate and dismiss all other knowledge.

So these Black epistemologies are important for establishing the significance of the experiences of people in the world who have been separated out, and constantly surveilled. This kind of knowledge have to be brought into conversation about how the world works. We think we know what we are talking about, but we actually are not saying very much. And the thing is, the dominant epistemologies that came out of Europe, particularly in the social sciences, look at a lot of things happening and sort of negate them because they don't fit in the paradigm. It's the building up of "anomalies" that's making the dominant approaches just seem ridiculous. Because you can't explain so many things, and you keep choosing to ignore them, as you negate that other knowledge count.

That's why Black epistemologies are extremely important. In many respects, it's a sort of Critical Race Studies, and it's the approach I'm taking when looking at the type of analysis being performed on the data collected by NYPD. I'm thinking in terms of the categories and the concepts that they're using to analyze the categories in which they are placing this data. So, if you only have categories that will assess the data that you're collecting in negative terms, then what is your output going to be? 
Therefore, it's crucial that we develop these other epistemologies, because it's with those developments that we will come up with new concepts, and the new categories to bring to bear. That way we can 1) challenge that work, and 2) transform it. That work has to change, as it's essentially reflecting the experiences of a very small portion of the population.

Ls: One final question in order to conclude. In the last few years we have been witnessing a great increase in the number of White supremacists, fascist movement, and far-right manifestations, be it under Trump administration as in other countries (like Brazil). So what are your perspectives for policing under these circumstances? And do you think police forces are prepared to deal with them? Because they have a lot to do with racial surveillance, in a way, but rather informal way of racial control, in a sense - not the State sense.

NB: So, what are my perspectives for policing within the context of this build-up of the right wing? I think the door is opening for greater amounts of repression. For example: there was an article that ran in the New York Times a few days ago about people detained in the migrant prisons - they don't call them prisons, but they're being detained - and I was completely blown away and constantly surprised at the stepping up of what I consider potentially repressive tactics and practices. I feel I shouldn't be, but I keep getting surprised at the ways in which they're instituting more policies and practices that open the door for greater repression.

For example, the Trump administration is essentially planning to collect - or expand the collection - of DNA for migrants who cross the border. And they want to include this in a criminal database that they're expanding and will be operated by the FBI. This policy hits on all that we have been talking about today, the surveillance, the Racial State, the definition of groups as a threat. They haven't told us much yet about what this increased testing is going to mean, but it's opening the door for great amounts of repression. I grow increasingly concerned and afraid for where things are headed.

LS: Me too. I think that would be all, and I want to thank you again for your availability.

Acknowledgments

Both interviewers are grateful to São Paulo Research Foundation (Fapesp), under the grants n. 2019/02612-0, and n. 2016/24525-3. 


\section{References}

Alexander, Michelle. (2010), The New Jim Crow: mass incarceration in the age of colorblindness. Nova York, The New Press.

Benjamin, Ruha. (2019), Race after technology: abolitionist tools for the New Jim Code. Cambridge, Polity.

Bhambra, Gurminder \& Holmwood, John. (2018), "Colonialism, postcolonialism and the liberal welfare state". New Political Economy, 23 (5): 574-587. Dor: 10.1080/13563467.2017.1417369.

Browne, Simone. (2015), Dark matters: on the surveillance of blackness. Durham, Duke University Press.

Byfield, Natalie. (2014), Savage portrayals: race, media \& the Central Park jogger story. Nova York, Temple University Press.

Goldberg, David. T. (2002), The racial state. Oxford, Blackwell Publishers.

Hall, Stuart. (1978), Policing the crisis: mugging, the state, and law and order. Londres, The Macmillan Press.

Murakawa, Naomi. (2016), The first civil right: how liberals built prison America. Nova York, Oxford University Press.

NeLSON, Alondra. (2016), The social life of DNA: race, reparations, and reconciliation after the genome. Boston, Beacon Press.

O'NeIL, Cathy. (2016), Weapons of math destruction: how big data increases inequality and threatens democracy. Nova York, Crown.

Zuboff, Shoshana. (2019), The age of surveillance capitalism: the fight for a buman future at the new frontier of power. Nova York, PublicAffairs.

Texto recebido em 28/5/2020 e aprovado em 12/8/2020.

DOI: 10.11606/0103-2070.ts.2020.176240.

Letícia Simốes-Gomes é pesquisadora do Núcleo de Estudos da Violência da Universidade de São Paulo (NEv/UsP). E-mail: le.simoesgomes@gmail.com.

Alcides Eduardo dos Reis Perón é pesquisador de pós-doutorado (Fapesp) no Departamento de Sociologia da Universidade de São Paulo (USP). E-mail: dudperon@gmail.com. 